\title{
Anaesthetic Induction with Alfentanil: COMPARISON WITH THIOPENTAL, MIDAZOLAM, AND ETOMIDATE
} de Lange MD FFarCs, David Koopman MD, Johan Spierdijk MD PH D, Jack van Kleef MD

The speed, side effects and cardiovascular changes as. sociated with anaesthetic induction and endotracheal intubation following alfentanil (20 $\mathrm{g} / \mathrm{kg} / \mathrm{min}, I \mathrm{~V})$, thiopental $(84 \mu \mathrm{g} / \mathrm{kg} / \mathrm{min}, \mathrm{IV})$, etomidate $\left(5 \mu \mathrm{g} / \mathrm{kg} / \mathrm{min}_{\text {, }}\right.$ IV) and midazolam $(20 \mu \mathrm{g} / \mathrm{kg} / \mathrm{min}$. IV) prior to halothane-nitrous oxide general anaesthesia were evaluated and compared in 80 patients undergoing elective general surgical operations. Anaesthetic induction was fastest with etomidate and thiopental (approximately one minute) and slowest with midazolam (about nwo minutes). Systolic arterial blood pressure (SBP) was decreased at the moment of unconsciousness with thiopental but unchanged with the other compounds. Heari rate (HR) was increased at unconsciousness with midazolom and thiopental but unchanged with etomidate and alfentanil. After intubation HR was increased in all groups except those induced with alfentanil. Arrhythrtias were infrequent (5 per cent or less in all groups). Rigidity during induction only occurred with alfentanil ( 55 per cent) and pain on injection only urith etomidate (35 per cent) and alfentanil (5 per cent). Postoperative vomiting was infrequent in all groups ( 15 per cent) except etomidate ( 55 per cent). No patient remembered any aspect of laryngoscopy or the operation and all rapidly regained consciousness at the end of operation. The results of this study demon.

From the Departments of Anesthesiology, The University of Utah School of Medicine, Salt Lake City, Utah, and The University of Leiden, Leiden, The Netherlands.

Aditress correspondence to: Theodore H. Stanley, MD, Department of Anesthesiology, The University of Utah School of Medicine, 50 North Medical Drive, Salt Lake City, Utah 84132.

Supported in part by Stanley Research Foundation. strate that with the exception of rigidity (which is easily overcome with succinylcholine) and a slightly stower onset of action, alfentanil compares favourably as an induction agent with thiopental and is better than midazolam and etomidate. Alfentanil is superior to all three other induction agents with respect to cardiovascular stability during induction and intubation.

\section{Key Words}

ANAESTHETICS, INTRAVENOUS: alfentanil; thiopental; midazolam; etomidate; INDUCTION: anaesthesia.

Alfentanil (N-[1-([2-ethyl-4, 5 dihydro-5-oxo-1Htetrazol-1-yl) ethyl]-4-(methoxymethyl)-4-piperidinyl]-N-phenyl-propanamine), is a new ultra-short acting, potent narcotic analgesic which is being evaluated as an intravenous supplement during nitrous oxjde anaesthesia., ${ }^{1,2}$ Alfentanil is chemically related to fentanyl (Figure 1) but is one-third as potent and has one-third the duration of activity as the latter. Animal data suggest that alfentanil has a faster onset of action than fentanyl. ${ }^{3}$ Because of its rapid onset of action, short duration of activity and lack of cardiovascular effects, we have suggested that alfentanil might be useful as an anaesthetic induction agent. ${ }^{4}$ In this study we evaluated and compared alfentanil, thiopental, etomidate and midazolam as anaesthetic induction agents prior to halothane- $\mathrm{N}_{2} \mathrm{O}$ anaesthesia for general surgical procedures.

\section{Methods}

The protocol was approved by the Leiden Univer- 


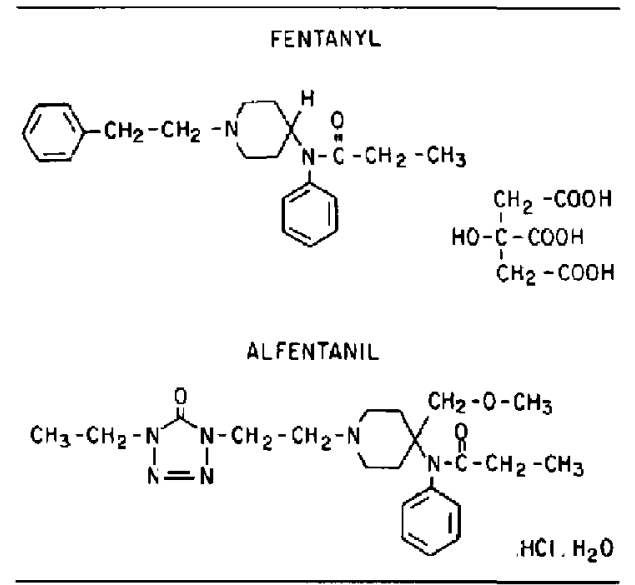

FIGURE I Structural formulae of alfentanil and fentanyl

sity Human Experimentation Committee. Informed consent to do the study was obtained from each patient at the time of the preoperative visit.

The experimental subjects were 80 patients (ASA class one or two) without a history of cardiac, pulmonary or renal disease, about to undergo short duration elective general surgical (abdominal, breast or thyroid) operations. Patients were randomly divided into four groups of 20 patients each. Group I was to have anaesthesia induced with alfentanil $(20 \mu \mathrm{g} / \mathrm{kg} / \mathrm{min})$, Group II thiopental $(84 \mu \mathrm{g} / \mathrm{kg} / \mathrm{min})$, Group III etomidate $(5 \mu \mathrm{g} / \mathrm{kg} /$ min), and Group IV midazolam $(20 \mu \mathrm{g} / \mathrm{kg} / \mathrm{min})$. These infusion rates were chosen (based on published reports and personal experience) to optimize speed of induction and minimize cardiovascular alterations and side effects.

All patients were premedicated with secobarbital (2.0 $\mathrm{mg} / \mathrm{kg}, \mathrm{PO})$ two hours preoperatively and atropine $(0.1 \mathrm{mg} / 15 \mathrm{~kg}$, IM) 30 minutes before the scheduled time of operation. Upon arrival in the operating room a catheter was placed in a hand vein and a bipolar lead II electrocardiogram continuously recorded. A standard Riva Rocci blood pressure cuff was used to measure systolic and diastolic arterial blood pressures. Heart and respiratory rates were determined by palpation of the radial artery and chest wall, respectively.

Following preparatory procedures, and a threeminute stabilization period, control blood pressures and heart and respiratory rates were recorded and the patients were given 100 per cent oxygen to breathe. Two minutes later pancuronium $(1.5 \mathrm{mg}$ / $70 \mathrm{~kg}$, IV) was given to reduce muscle fasciculations from succinylcholine and rigidity from alfentanil. Three minutes after pancuronium, one of the four induction agents was administered intravenously until the patient was unconscious. During the induction process, patients were commanded to open their eyes and take a deep breath every five to ten seconds. Failure to respond to three consecutive commands was equated with unconsciousness. Respirations were first spontaneous and then assisted (when respiratory rate and/or tidal volume diminished). If breathing stopped, ventilation was controlled using a face mask and a non-rebreathing system. When unconscious, the patients were paralyzed with intravenous succinylcholine $(1.5 \mathrm{mg} / \mathrm{kg})$ and had their tracheas intubated with a cuffed tracheal tube. After intubation, all patients received halothane (0.2-1.5 per cent) and nitrous oxide ( 60 per cent) in oxygen as the only other anaesthetics for the remainder of the operation. Halothane concentrations were regulated to maintain systolic arterial blood pressure within \pm 15 per cent of control. Patients were paralyzed with pancuronium $(0.05 \mathrm{mg} / \mathrm{kg}$, slowly intravenously, 20 minutes after intubation followed by $1-2 \mathrm{mg}$ increments every 45-60 minutes throughout the operation). At the conclusion of the operation neuromuscular blockade was antagonized with neostigmine (1$2 \mathrm{mg})$ and atropine $(0.5 \mathrm{mg})$ intravenously. Arterial blood pressure and heart rate were recorded immediately before beginning anaesthetic induction, at the moment of unconsciousness, one minute after succinylcholine (before endotracheal intubation) and one minute after tracheal intubation.

Other variables evaluated during induction included: pain with injection of the induction agents (patients were questioned during infusion and 24 hours postoperatively); the presence of arthythmias; the time to unconsciousness; the presence of muscle (chest wall) rigidity, evaluated as follows: no rigidity $=$ no difficulty with ventilation during manual positive pressure ventilation and no clinical evidence of abdominal wall (as determined by palpation) or upper limb stiffness (as determined by manual elbow flexion); mild rigidity = can ventilate but with some difficulty associated with mild abdominal wall and/or upper limb stiffness; severe rigidity $=$ virtually impossible to ventilate prior to 
TABLE 1 Preoperative Data (mean \pm SD)

\begin{tabular}{|c|c|c|c|c|c|c|}
\hline & \multirow{2}{*}{$\begin{array}{l}\text { Age } \\
\text { (years) }\end{array}$} & \multirow{2}{*}{$\begin{array}{l}\text { Weight } \\
(\mathrm{kg})\end{array}$} & \multirow{2}{*}{$\begin{array}{l}\text { Preanaesthetic } \\
\text { Heart Rate } \\
\text { (beats/min) }\end{array}$} & & \multicolumn{2}{|c|}{ Preancesthetic Blood Pressure } \\
\hline & & & & & Systolic & Diastolic \\
\hline \multirow[t]{2}{*}{ Group I } & 44 & 67 & 77 & \multirow[t]{2}{*}{ torr } & 142 & 93 \\
\hline & \pm 11 & \pm 10 & \pm 11 & & \pm 11 & \pm 6 \\
\hline (Alfentanil) & & & & $\mathbf{k P a}$ & $\begin{array}{l}(18.9) \\
( \pm 1.5)\end{array}$ & $\begin{array}{r}(12.4) \\
( \pm 0.8)\end{array}$ \\
\hline Group II & 39 & 73 & 83 & torr & 143 & 94 \\
\hline (Thiopental) & \pm 11 & \pm 9 & \pm 9 & pKa & $\begin{array}{l} \pm 10 \\
(19.0) \\
( \pm 1.3)\end{array}$ & $\begin{array}{l} \pm 8 \\
(12.5) \\
( \pm 1.1)\end{array}$ \\
\hline Group III & $\begin{array}{r}38 \\
\pm 10\end{array}$ & $\begin{array}{r}70 \\
\pm 8\end{array}$ & $\begin{array}{r}81 \\
\pm 10\end{array}$ & tort & $\begin{array}{r}138 \\
\pm 10\end{array}$ & $\begin{array}{r}90 \\
\pm 8\end{array}$ \\
\hline (Etomidate) & & & & $\mathrm{pKa}$ & $\begin{array}{r}(18.4) \\
( \pm 1.3)\end{array}$ & $\begin{array}{r}(12.0) \\
( \pm 1.1)\end{array}$ \\
\hline \multirow[t]{2}{*}{ Group IV } & 42 & 70 & 80 & \multirow[t]{2}{*}{ tor } & 139 & 89 \\
\hline & \pm 10 & \pm 8 & \pm 9 & & \pm 9 & \pm 9 \\
\hline (Midazolam) & & & & $\mathrm{pKa}$ & $\begin{array}{r}(18.5) \\
( \pm 1,2)\end{array}$ & $\begin{array}{r}(11.8) \\
( \pm 1.2)\end{array}$ \\
\hline
\end{tabular}

succinylcholine administration associated with marked abdominal wall, face, neck, or upper limb stiffness.

At the end of operation patients were extubated if they had a spontaneous respiratory rate of 12 breaths/min or greater and a tidal volume (measured with a Wright Respirometer) of $7 \mathrm{ml} / \mathrm{kg}$ or more. Patients not fulfilling our criteria for extubation were taken to the recovery room and mechanically ventilated until criteria for extubation were fulfilled. Re-evaluation in the recovery room took place every five to ten minutes. Variables evaluated in all patients in the mandatory three-hour recovery room stay included the presence of nausea or vomiting, the presence of pain that could not wait beyond three hours for treatment with an analgesic (patient's decision) and the somnolence score. The somnolence score was determined on entrance to the recovery room, 15 minutes later, and every 15 minutes thereafter for three hours. Somnolence was evaluated by the method of Bidwai et al., ${ }^{5}$ where 4 $=$ patient unresponsive to verbal command or painful (pinprick) stimulation; 3 = patient responds to painful stimulation but not to verbal command, 2 = patient responds to verbal command but is disoriented and does not initiate conversation; $1=$ patient responds to all forms of stimulation, is well-oriented but feels sleepy and does not initiate conversation; $0=$ patient is oriented and initiates conversation. Recovery room evaluations were performed by nursing personnel who were unaware of which agent had been used for anaesthetic induction.

All patients were interviewed $24-48$ hours postoperatively. Questions were specifically directed at determining the last and first things remembered before anaesthetic induction and after recovery from anaesthesia, the incidence of vomiting, other negative features of the recovery period and whether patients remembered any aspect of laryngoscopy, tracheal intubation or the operative procedure.

Data were analyzed for statistical significance using Student's paired and unpaired t-tests, analysis of variance, and the chi-square test. $p<0.05$ was considered statistically significant.

\section{Results}

The ages, weights, types of operations, length of operations (101 $\pm 19 \mathrm{~min}$, mean $\pm S D$ ) and preoperative blood pressures, heart and respiratory rates were similar in the four groups (Table I). Requirements for unconsciousness were as follows: alfentanil $173 \pm 5 \mu \mathrm{g} / \mathrm{kg}$; thiopental $3.82 \pm 0.4 \mu \mathrm{g} /$ $\mathrm{kg}$; etomidate $309 \pm 25 \mu \mathrm{g} / \mathrm{kg}$ and midazolam 226 $\pm 22 \mu \mathrm{g} / \mathrm{kg}$. Thiopental and etomidate produced unconsciousness in the shortest time ( $58 \pm 16$ and $62 \pm 19$ seconds, respectively) and midazolam took 
CANADIAN ANAESTHETISTS' SOCIETY JOURNAL

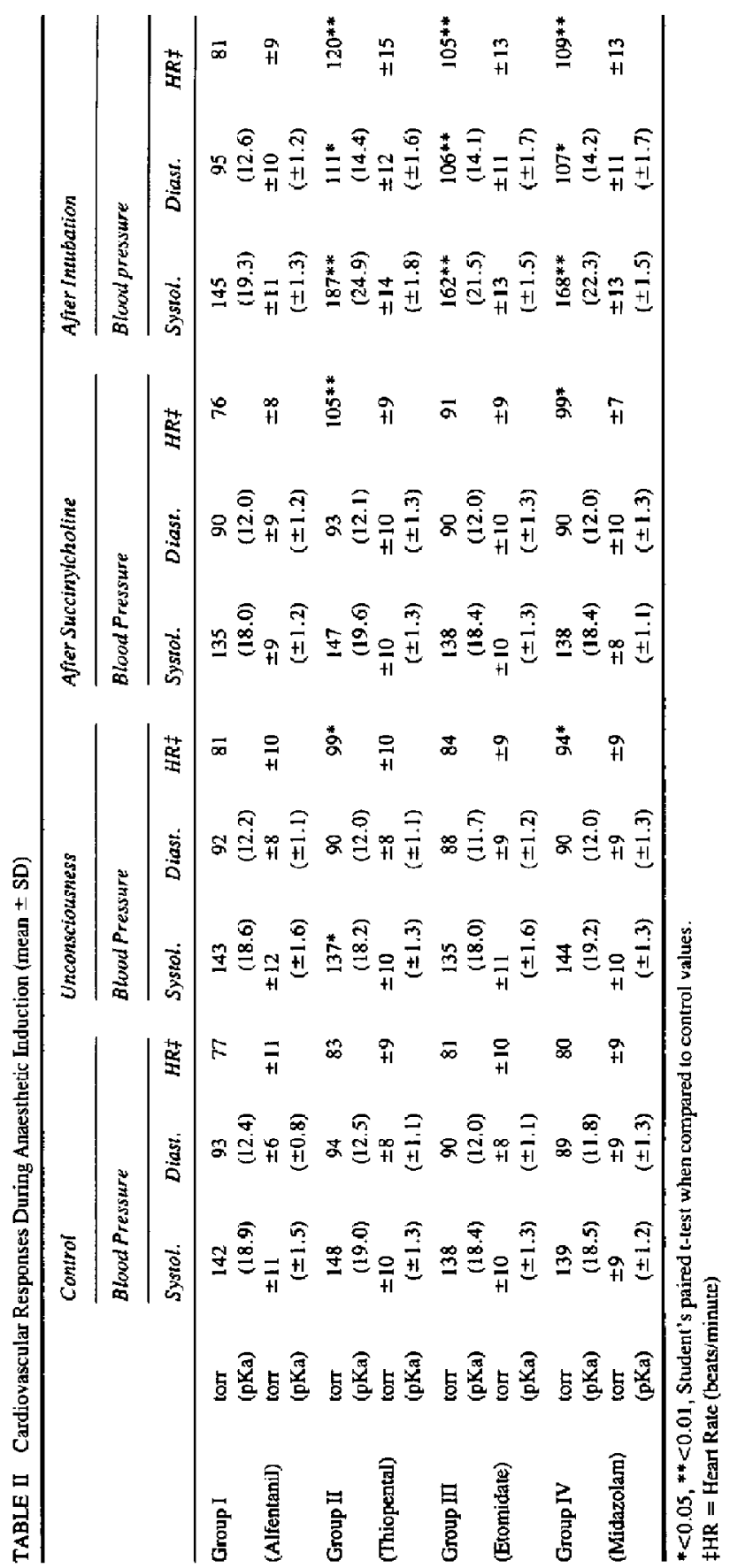


TABLE III Incidence of Side Effects During and After Anaesthesia (per cent)

\begin{tabular}{llllll}
\hline & $\begin{array}{l}\text { Arrhythmias } \\
\text { on Intubation }\end{array}$ & $\begin{array}{l}\text { Rigidity } \\
\text { on Intuhation }\end{array}$ & $\begin{array}{l}\text { Pain an } \\
\text { Injection }\end{array}$ & $\begin{array}{l}\text { Postoperative } \\
\text { Vomiting }\end{array}$ & $\begin{array}{l}\text { Recovery Room } \\
\text { Analgesic }\end{array}$ \\
\hline $\begin{array}{l}\text { Group I } \\
\text { (Alfentanil) }\end{array}$ & 0 & $55^{*}$ & 5 & 15 & 35 \\
$\begin{array}{l}\text { Group II } \\
\text { (Thiopental) }\end{array}$ & 5 & 0 & 0 & 15 & 45 \\
$\begin{array}{c}\text { Group III } \\
\text { (Etomidate) }\end{array}$ & 5 & 0 & $35^{*}$ & $50^{*}$ & $75^{*}$ \\
$\begin{array}{c}\text { Group IV } \\
\text { (Midazolam) }\end{array}$ & 5 & 0 & 0 & 15 & 45 \\
\hline
\end{tabular}

"p $<0.05$, Chi-square test when compared to thiopental group.

the longest (116 \pm 29 seconds). Induction with alfentanil took an average of $93 \pm 24$ seconds. Differences in induction time between thiopental and alfentanil $(\mathrm{p}<0.05)$ and midazolam $(\mathrm{p}<0.01)$ were statistically significant (Student's unpaired t-test).

Systolic arterial blood pressure was decrcased with unconsciousness after thiopental but remained unchanged at this time with the other induction compounds, Table ir. Following tracheal intubation systolic blood pressure was markedly increased in all groups except the alfentanil group in which it remained unchanged, Heart rate was increased at unconsciousness with thiopental and midazolam but remained unchanged at this time in the other groups, Table II. Heart rate was increased after intubation in all groups except those induced with alfentanil in which it remained unchanged. Diastolic blood pressure remained unchanged in the alfentanil group throughout the study but was significantly increased in all other groups following tracheal intubation (Table II).

All but three patients, one in the alfentanil group and two in the midazolam group were extubated on the operating room table and taken to the recovery room with adequate spontaneous respiration. The latter three patients had short operations $(25,60$ and 65 minutes, respectively) and required mechanical respiratory assistance in the recovery room (for 5 , 32 , and 30 minutes, respectively).

Sornnolence scores upon entry to the recovery room were two or lower in most patients. Only 14 patients in the entire study (four in the alfentanil group, two each in the thiopental and etomidate groups, and six in the midazolam groups had somnolence levels of three or four on entrance to the recovery room. None of these scores remained above two after 45 minutes in the recovery room and most were at levels of two or lower after 15 minutes. Differences in the somnolence levels between the groups were not statistically significant at any time in the post-anaesthetic period.

Arrhythmias (premature ventricular contractions) occurred during induction in one patient in all groups except the alfentanil group (none in the latter group experienced arrhythmias) (Table IIr). These arrhythmias were transient and did not require therapeutic measures. Muscle or chest wall rigidity occurred only in the alfentanil group (55 per cent of patients in this group) (Table ill). Rigidity rapidly disappeared after succinylcholine and was never a problem. No patient in this study was aware of chest wall or muscle rigidity. Pain on injection occurred in seven patients ( 35 per cent) in the etomidate group and one (five per cent) in the alfentanil group but not in any patients in the other groups. Postoperative vomiting occurred in three patients (15 per cent) in each of the alfentanil, thiopental and midazolam groups but in ten patients ( 50 per cent) of those in the etomidate group (Table III).

No patient in the alfentanil group required a concentration of halothane greater than 1.0 per cent at any time during the study to maintain systolic arterial blood pressure within \pm 15 per cent of preoperative control values. Some patients in all other groups required halothane concentrations above 1.0 per cent at intervals during operation for blood pressure control. Fifteen of the 20 patients of the etomidate group required an analgesic at some time in the recovery room. Some analgesic medication was required by nine patients in each of the thiopental and midazolam groups but in only seven 
of the alfentanil group, Table III. Differences between the etomidate group and all other groups with respect to analgesic needs in the recovery room were statistically significant.

When interviewed postoperatively, all patients related that the last thing they remembered was either coming to the operating room or having a mask placed on their face and the first thing after anaesthesia, their presence in the operating or recovery rooms. No patient in the study remembered laryngoscopy, tracheal intubation, or any aspect of the operative procedure.

\section{Discussion}

An ideal anaesthetic induction agent should produce a rapid and pleasant abolition of consciousness with minimal or no cardiovascular, respiratory or other major organ system alterations, possess few or no side effects and have a short duration of action. $^{6-9}$ Although it is unlikely that a drug fulfilling all these criteria will be found in the near future, intravenous sodium thiopental has, for many years, been the compound closest to being ideal and, at least in North America, is the most popular intravenous anaesthetic induction agent.

Recent interest in preventing even transient changes in heart rate and arterial blood pressure, especially in patients with cardiac disease, ${ }^{11,12}$ has focused on one of the most serious deficiencies of sodium thiopental, the cardiovascular alterations following anaesthetic induction and tracheal intubation. ${ }^{8,10-15}$ Because thiopental is a myocardial depressant and capacitance vessel dilator, hypotension during anaesthetic induction is not unusual. ${ }^{13-15}$ While hypotension can be minimized by slow infusion of thiopental ${ }^{14}$ it often cannot be eliminated (as was observed in this study). Furthermore, hypotension after thiopental is usually followed by hypertension and tachycardia (often severe) after tracheal intubation. ${ }^{10-12}$ The latter changes may be more worrisome than hypotension in patients with ischaemic cardiac disease and have stimulated keen interest in the use of other drugs, along with sodium thiopental (i.e., local anaesthetics, antic-cholinesterases, vasodilators) to prevent or rapidly correct hypertension and tachycardia following tracheal intubation. ${ }^{10-12}$ Unfortunately, this therapy is often ineffective, makes anaesthetic induction more complex and introduces the possibilities of hypotension and/or bradycardia.
Another approach has been to develop newer, short-acting non-barbiturate hypnotic compounds that might replace thiopental and its congeners. ${ }^{16,17}$ This has led to interest in new benzodiazepines (midazolam), steroid anaesthetics (althesin), eugenols (propanidid), and GABA (Gama Amino Butyric Acid) receptor stimulators (etomidate), as intravenous anaesthetics and induction agents. ${ }^{16,17}$ While there has been some enthusiasm for these compounds as anaesthetic induction agents, many of them have either had a higher incidence of side effects (etomidate) or more serious side effects (anaphylaxis, althesin and propranidid) than thiopental. To a certain extent this was observed in this study. Other anaesthetic agents have not been reliable or have had quite prolonged induction and/or recovery times (diazepam). ${ }^{16,17}$ Cardiovascular depression equal to or greater than that of the ultra-short acting barbiturates has also been characteristic of some compounds (propanidid). ${ }^{17}$ All of the new hypnotics appear deficient in analgesic properties and thus are unable to block hypertension and tachycardia following endotracheal intubation. ${ }^{17}$ For this reason we wondered whether a narcotic compound with a fast onset of action and short duration of activity might be of benefit as an anaesthetic induction agent.

Our initial studies with patients premedicated only with atropine indicated that alfentanil fulfills many of the criteria of an ideal intravenous induction agent. ${ }^{4}$ It has a fast onset of action (although a little slower than thiopental), a short duration of activity after a single bolus, 10-15 minutes (Stanley $\mathrm{TH}$, unpublished data), few side effects (although chest wall rigidity is a significant one) and most importantly, produces little change in cardiovascular dynamics during anaesthetic induction and after endotracheal intubation. ${ }^{4}$ Our findings in this study confirm the original results and suggest that alfentanil compares favorably with three other compounds that are being used or might (midazolam) be used as intravenous anaesthetic induction agents in clinical setting,

Rigidity of thoracic and occasionally abdominal and upper extremity muscles is a problem with anaesthetic induction with alfentanil or any of the fentanyl-related narcotics. ${ }^{4,18-21}$ Simultaneous administration of a large dose of a muscle relaxant (depolarizing or non-depolarizing) eliminates rigidity but a large bolus of some muscle relaxants can 
cause cardiovascular alterations themselves (hypotension, d-tubocurarine; hypertension and tachycardia; pancuronium). ${ }^{4,18}$ There are data which indicate that a benzodiazepine premedication reduces the incidence of chest wall rigidity with alfentanil. ${ }^{4}$ Unfortunately, benzodiazepines can potentiate and prolong the actions of alfentanil (de Lange $S$, Stanley $T H$, unpublished data) as well as all narcotics. ${ }^{22.23}$ Our experience has suggested that pretreatment with a non-depolarizing muscle relaxant before induction with alfentanil or any of the fentanyl-like drugs reduces the incidence and severity of thest wall rigidity. ${ }^{4 *}$ However, in spite of this therapy some rigidity was noted in 55 per cent of patients having anaesthesia induced with alfentanil in this study. In defence of alfentanil, or for that matter, all narcotics used for anaesthetic induction, it is reire that mechanical ventilation is impossible following induction, in spite of chest wall rigidity. However, even if it is momentarily impossible to mechanically ventilate patients following a narcotic induction, there is no problem if the patient has been pre-oxygenated and an intravenous infusion is available for succinylcholine administration.

In conclusion, the results of this study demonstrate that with the exception of rigidity, which is easily overcome with intravenous succinylcholine, and a slightly slower onset of action, alfentanil compares favourably as an induction agent with thiopental and is better than midazolam and etomidate. Alfentanil is superior to all three other induction agents with respect to cardiovascular stability during anaesthetic induction and may also be in terms of minimizing intraoperative inhalation anaesthetic requirements.

* de Larige S, Staniey Th, Bascoe M. Fentanyl-oxygen anesthesia: Comparison of anesthetic requircments and cardiovascular responses in Salt Lake City and Leiden, Holland. Abstracts 7 th World Congress of Anaesthesiologists, Hamburg, 1980, p. 313.

\section{References}

$1 K a y$ B, Stephenson DK. Alfentanil (R39209): Initial clinical experience with a new narcotic analgesic. Anaesthesia 1980; 35: 1197-201.

2 Kay B, Pleuvry B. Human volunteer studies of alfentanil (39209), a new short-acting narcotic analgesic. Anaesthesia 1980; 35: 952-6.

3 de Castro J, van de Water $A$, Wouters $L$, Xhonneux $R$, Renemun $R, K a y B$. A comparative study of eight narcotics in dogs. Acta Anaesthesiolog Belg 1979; 30: 5-54.

4 Nauta J, de Lange S, Koopman D, Spierdijk J, Van Kleef J, Stanley TH. Anesthetic induction with alfentanil: a new short acting narcotic analgesic. Anesth Analg 1982; 61: 267-72.

5 Bidwai AV, Cornelius LR, Stanley TH. Reversal of Innovar induced postanesthetic somnolence and disorientation with physostigmine. Anesthesiology 1976 ; 44: 249-51.

6 Fox GS, Wynands HE, Bhambhambi $M$. A clinical comparison of diazepam and thiopentone as induction agents to general anaesthesia. Can Anaesth Soc J 1968; 15: 281-90.

$7 \mathrm{McClish} A$. Diazepam as an intravenous induction agent for general anesthesia. Can Anaesth Soc J $1960 ; 13: 562-75$.

8 Guerra $F$. Thiopental forever after, Trends in Intravenous Anesthesia. Edited by Aldrete JA, Stanley $T H$. Chicago, Year Book, 1980, pp 143-51

9 Dundee JW. The ideal anesthetic(s), Trends in Intravenous Anaesthesia. Edited by Aldreie $J A$, Stanley TH. Chicago, Year Book, 1980, pp 127142.

10 Stoelting RK. Attenuation of blood pressure response to laryngoscopy and tracheal intubation with sodium nitroprusside. Anesth Analg 1979; 58 : $116-9$.

11 Stoelting $R K$. Circulatory changes during direct laryngoscopy and tracheal intubation. Influences of duration of laryngoscopy with or without prior lidocaine. Ancsthesiology 1977; 47: 381-4.

12 Bidwai, AV, Rogers CR, Stanley TH, Wong KC. Gibbs $S$. Effect of edrophonium on heart rate and blood pressure responses to tracheal intubation. Anesthesiology 1980; 53: \$131.

13 Conway $C M$, Ellis $D B$. The haemodynamic effects of short acting barbiturates. Br J Anaesth 1969; 4!: $534-42$.

14 Etsten $B, L i T$. Hemodynamic changes during thiopental anesthesia in humans: cardiac output, 
stroke volume, total peripheral resistance and intrathoracic blood volume. J Clin Invest 1955; 34: 500-10.

15 Eckstein JW, Hamilton WK, MacCammond JM The effects of thiopental on peripheral venous tone. Anesthesiology 1961; 22: 525-8.

16 Aldrete JA, Stanley $T H$. Trends in Intravenous Anesthesia. Chicago, Year Book, 1980.

17 Stanley $T H$. Pharmacology of Intravenous NonNarcotic Anesthetics. In Anesthesia, Edited by Miller $R$. Churchill-Livingstone, Inc. New York, 1981, Chapter 10.

18 Hill $A B$, Nahrwold ML, de Rosayro AM, Knight $P R$, Jones $R M$, Bolls RE. Prevention of rigidity during fentanyl-oxygen induction of anesthesia. Anesthesiology $1981 ; 55: 452-4$.

19 de Lange S, Stanley TH, Boscoe $M B$. Comparison of sufentanil- $\mathrm{O}_{2}$ and fentanyl- $\mathrm{O}_{2}$ anesthesia for coronary artery surgery. Anesthesiology 1982; 56: 112-8.

$20 \mathrm{de}$ Castro J. Practical applications and limitation of analgesic anaesthesia. Acta Anaesthesiolog Belg 1976; $27: 107-28$.

21 de Lange S, Stanley TH, Boscoe $M J$. Alfentaniloxygen anaesthesia for coronary artery surgery. $\mathrm{Br} \mathrm{J}$ Anaesth 1981; 53: 1291-6.

22 Stanley $T H$, Webster $L R$. Anesthetic requirements and cardiovascular effects of fentanyl-oxygen and fentanyl-diazepam in man. Anesth Analg 1978; 57: 411-6.

23 Stantey TH, Bennett GM, Loeser EA, Kawamura $R$, Seniker $C R$. Cardiovascular effects of diazepam and dropiderol during morphine anesthesia. Anesthesiology 1976; 44: 255-7.
Résumé

On a mesuré la vitesse d'induction anesthétique, les effets secondaires et les changements cardio-vasculaires associés d l'induction et l' inubation trachéales après

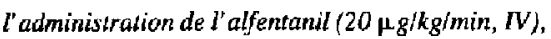
Le chiopental ( $84 \mu \mathrm{g} / \mathrm{kg}$ imin, IV), l'étomidate $(5 \mu \mathrm{g} /$ $\mathrm{kg} / \mathrm{min}, \mathrm{IV}$ ) et le midazolam $(20 \mu \mathrm{g} / \mathrm{kg} / \mathrm{min}, I V)$ antérieurement à l' administration d' halotane de protoxyde d'azote pour l'anesthésie générale. On a évalué et comparé cette induction chez 80 patients réglés pour interventions chirurgicales générales. L' induction anesthétique avec l'étomidate et le thiopental (approximativement une minute) se faisait plus rapidement, mais plus lentement avec le midazolam (environ deux minutes). La tension artárielle systolique (TAS) baissa dès l' instant où le patient s' endormil avec la dose de thiopental mais ne changea pas avec les autres composés. La fréquence cardiaque (FC) augmenta chez les patients endormis recevant le midazolam mais resta inchangée avec l'étomidate et l'alfentanil. Après i' intubation, la fréquence artérielle $(F A)$ s'éleva chez tous les groupes mais non pas chez ceux recevant l'alfentanil. L'aryhthmie était moins fréquente (5 pour cent ou moins chez tous les groupes). On observa ure rigidité seulement avec l' induction de l' alfentanil (55 pour cent) et une sensation de douleur avec l' injection d'étomidate (35 pour cent), avec l'alfentanil (5 pour cent). Les vomissements post-opératoires sont infréquents chez tous les groupes (15 pour cent) sauf chez ceux recevant l' étomidate (55 pour cent). Aucum patient ne se souvient de l' intervention chirurgicale ni de la laryngoscopie et la période de réveil s' effectua rapidement vers la fin de l'opération chirurgicale. Les résultats de cette recherche démontrent donc que à part la rigidité fqui est facilement corrigée avec le succinylcholine) et un leger début d' inhibition, l'alfentanil est un agent favorable d'induction avec le thiopental et est plus efficace que le midazolam et l'étomidate. L'alfentanil est un agent superieur d'induction comparé aux srois autres agents par rapport a sa stabilité cardiovasculaire observée pendunt l' induction et l' intubation. 